\title{
Corporate Social Responsibility Reporting among European \\ Low-Fares Airlines: Challenges for the Examination and \\ Development of Sustainable Mobilities
}

Tim Coles*, Emily Fenclova and Claire Dinan

Centre for Sport, Leisure and Tourism Research, University of Exeter Business School.

Streatham Court, Rennes Drive, Exeter, United Kingdom. EX4 4PU

(t) +44-1392-724441 (f) +44-1392-722363 (e) t.e.coles@ex.ac.uk

\footnotetext{
* Corresponding author
} 


\title{
Corporate Social Responsibility Reporting among European \\ Low-Fares Airlines: Challenges for the Examination and Development of Sustainable Mobilities
}

\begin{abstract}
This paper examines corporate social responsibility (CSR) practices among the growing Low-Fares Airlines (LFAs) flying between mainland Europe and the UK. A mixed methods approach was employed combining a content analysis of 22 airlines' documentation with key-informant interviews with 11 airlines including three of the four market leading LFAs. The research discovered evidence that LFAs were aware of the need to act more responsibly but how far intentions resulted in action was difficult to establish. To date the examination of LFAs has relied heavily on secondary sources and perspectives external to the firm. The firms' own CSR-related texts do not represent a reliable basis for examining responsibility among LFAs; they have a high degree of fragmentation and variable quality. In-depth interviews showed that while there is more CSR activity than is made public, incomplete knowledge was a more significant problem than bias or spin. Very few LFAs had conducted a systemic audit of CSR-related activity. Integrative approaches are required to overcome the limitations of single methods, to contribute towards a fuller understanding of responsibility among LFAs, and to inform debate on whether it is necessary to regulate in order to encourage sustainable development in this high growth sector.
\end{abstract}

\section{Introduction: sustainable development, aviation and responsibility}

An enduring issue over the past 20 years has been how far support for the principles of sustainable development has resulted in behavior change. On the supply-side, Sheldon and Park (2011) identified an 'importance-performance' gap. The need for more responsible business management has been acknowledged but not necessarily 
translated into action. A similar 'intention-behaviour gap' has emerged on the demandside (Barr et al, 2011). Many citizens adopt sustainable practices in their homes which reflect their intentions, but they are not reflected in their travel choices or behaviours. Such a duality has featured in discourse on low-fares airlines (LFAs) and their role in sustainable mobilities (Graham and Shaw 2008; Coles, Fenclova and Dinan 2011). Also called 'low cost carriers' or 'no frills airlines', LFAs - such as easyJet, Ryanair, Flybe and Air Berlin- practice lean production and cost reduction to offer cheaper tickets than their 'full service' competitors, typically former national or 'flag carriers' (Franke, 2004; Gro $\beta$ and Schröder, 2007). One underlying and highly contested question has been the extent to which it is necessary for the state to regulate to ensure that acknowledgement of the importance of sustainable development features in LFA practice (ELFAA, 2004; ECI, 2005; Graham and Shaw, 2008; Oxford Economics, 2009). Aviation is the subject of many supra-national agreements and conventions (Duval, 2008). Trade bodies and associations -as well as individual airlines- have resisted, and continue to oppose, attempts to curb their commercial freedoms by imposing greater regulation (IATA, 2012a). Instead, they argue that the aviation sector alone is best able to respond to global challenges such as climate change (IATA 2012b; Gössling and Peeters 2007). In other words, self-regulation is the most appropriate means by which to engineer more sustainable mobilities in air transport.

This paper examines Corporate Social Responsibility (CSR) practices among LFAs flying between Europe and the UK. This group of airlines was chosen partly because the UK is a major European market for LFA operations (DLR 2011) and because, since 2003, the UK government has overtly connected aviation policy with the principles of sustainable development (DfT 2003). The paper contributes to debates about sustainable mobilities by using and calling for more sophisticated methodological approaches to empirical research on LFAs in responsible business management. Following a literature review, the second section argues that responsibility is an 
important, but overlooked feature in research on LFAs and sustainable development. The third section outlines the research strategy used to inform this paper. In the fourth section, the way in which CSR was portrayed by LFAs in their reporting texts is juxtaposed with findings from key-informant (elite) interviews. The final section discusses findings as well as the policy and conceptual implications for discourse on sustainable mobilities arising from the issues that this paper exposes.

\section{Literature review}

With its progressive airline deregulation, the European Union has been at the heart of the so-called 'low cost revolution' (ELFAA, 2004). By 2009, LFAs accounted for an estimated 35\% of all scheduled intra-European traffic (ELFAA, 2009) and the largest LFA, Ryanair, appeared in the list of the world's largest 20 airlines by revenue passenger kilometers, a basic measure of total production (DLR 2011, p8). This major restructuring of air passenger markets has been accompanied by a protracted discourse involving the academy, policy-makers and popular media about its desirability in the context of sustainable development. The essence of this is that economic deregulation and the dismantling of internal barriers to growth may have encouraged innovation, growth and a more competitive market in aviation but at what environmental cost? Within the UK, the European market is at the forefront of this growth in terms of growth in routes and passenger numbers (DLR 2011). However, issues like noise and visual pollution, increased emissions, and the possible contribution to climate change have been the focus of on-going attention (Mann, 2004; Gibbons, 2008; Sinclair, 2007). Doubts have been raised about whether LFAs can act more responsibly, in a manner expected of organizations adhering to the principles of sustainable development, but offering cheaper aviation in the short-term with little obvious regard for their (mainly environmental) impacts in the medium- to long-term (ECI, 2005; Treasury, 2008). Detractors have alleged that LFAs are a major driver behind increased emissions and 
noise pollution. Furthermore, they have variously argued that LFAs encourage 'trivial travel'; that the socio-economic range of travellers has not widened; they create unsustainable influxes of seasonal visitors; and the case for regional economic development does not stand up to scrutiny (Graham and Shaw, 2008; Coles et al, 2011).

Such positions are hotly contested by the airlines and their trade bodies (Gössling and Peeters 2007). They counter environmental criticisms by contending that they are acting in a more environmentally-responsible manner through technological innovations like winglets; investment in new, more efficient fleets; and eco-labeling schemes that allow customers more data to inform their travel choices (Flybe 2008; Ryanair 2008; easyJet 2008). Moreover, LFAs and their proponents have claimed that they have promoted sustainable development through increased accessibility and investment to previously transport-disadvantaged regions; lower costs have translated into lower fares and wider, more socially-equitable travel; and because lean production encourages more parsimonious resource use (ELFAA, 2004; York Aviation, 2007; Gro $\beta$ and Schröder, 2007; Rey et al, 2011).

This is a necessary simplification of a large and intricate body of knowledge but three features are important here. First, within the discourse there has been a tendency to privilege the environmental at the relative expense of the economic and, in particular, the social (ECI 2005; Gössling and Peeters, 2007; Treasury, 2008; Omega, 2008). The full 'triple bottom line' has been acknowledged but de facto greatest weight has been given to the environmental dimensions of sustainable development. Second, critics and advocates alike have been reliant on secondary data, largely put in the public domain by LFAs, their trade associations, and regulatory bodies. Almost exclusively external perspectives -that is, from commentators outside the airlines- have driven public debate about LFAs (Gro $\beta$ and Schröder, 2007; Graham and Shaw, 2008). As a result, current assessments of their role in sustainable mobilities is methodologically limited and based 
on partial data. Finally, consideration of CSR issues has been missing from the discussion, especially discussion of internal LFA operations and practices.

According to the European Commission, CSR is a 'concept whereby companies integrate social and environmental concerns in their business operations and in their interactions with their stakeholders on a voluntary basis' (CEC 2006 p5), while the World Business Council for Sustainable Development (WBCSD, 1999 p3) views CSR as 'the continuing commitment by business to behave ethically and contribute to economic development while improving the quality of life, of the workforce, and their families, as well as the local community and society at large'. There are many contested definitions of CSR (Dahlsrud, 2008; Okoye, 2009); however, the salient point is that CSR is best conceptualized at the level of the individual business as a means of delivering higher aspirations for, and collective action necessary to achieve, sustainable development (Plume, 2001 p21ff). At a micro-level, CSR is concerned with how the 'triple bottom line' is affected by the operations of an organization, the extent to which the organization is conscious of these impacts, and how it acts voluntarily to ensure the most beneficial outcomes for all its stakeholders, both internally and externally. The latter are not only customers, shareholders or investors but also the regulators, policy actors and the wider communities which businesses serve. Therefore, as an approach to business administration, CSR requires organizations to question the extent to which their internal practices and stakeholders adhere to, and deliver on, the principles of sustainable development; that said, debate on LFAs has focused to date on externalities and external stakeholders (ELFAA 2004; York 2007; Groß and Schröder, 2007; Graham and Shaw, 2008).

Within tourism studies, interest in CSR has grown, in particular as it relates to tour operators and accommodation providers (cf. Miller, 2001; Holcomb et al, 2007; Sheldon and Park, 2011; de Grosbois, 2012). Far less attention has been afforded to aviation (Amaeshi and Crane, 2006; Phillips, 2006. ). As Lynes and Andrachuk (2008 
p378) have observed, this is curious, because aviation 'possesses several characteristics similar to those of manufacturing industries.... where there has been considerable research ' ....including intense regulation, high entry barriers, high capital costs, and tendencies towards oligopolies'. Specifically, they note the importance of sectoral and cultural contexts in shaping SAS's approach to CSR, heavily influenced as it is by the ideology of social democracy in Scandinavia and the value placed regionally on the environment. A more wide-ranging survey of 41 'flag carriers' in the three main global alliances found that only 14 had annual reports in the public domain in 2009 (CowperSmith and de Grosbois, 2010). Within these reports environmental features predominated, specifically emissions reductions programmes. Variations in the scope and content of reporting and measurement frustrated attempts to make cross-sectoral comparisons. On LFAs, Coles et al (2011) found inter-regional variations in external stakeholders' perceptions and valorisations of CSR in peripheral regions of the UK. This was based on distinctive regional contexts and unfolding experiences of recession.

Thus, it is clear that a more thorough and conceptually-informed examination of CSR among LFAs requires careful consideration of their internal practices as well as their actions and outcomes as they relate to external stakeholders. Epistemologically, this duality requires knowledge production from multiple data sources. In terms of research paradigms in the social sciences, it is likely to have a strong behaviouralist tendency (Lukes 2005). This is because it relies on overt observations of practices (or not as the case may be) by and within the firm. Methodologically, to be conceptually faithful, empirical research strategies should integrate data from both intra- and extraorganizational inspection of organizations (Porter and Kramer, 2006). Within organizations, interviews, archival searches, observations and/or participation in action research offer significant explanatory potential (Blowfield and Murray, 2008). However, with the notable exception of work on the Hilton and Scandic hotel chains (Bohdanowicz and Zientara 2008, 2009; Bohdanowicz, Zientara and Novotna, 2011), the firm per se has 
been the (impenetrable) unit of analysis in tourism studies of CSR and there has been a failure to examine activity within and across its divisions.

When combined with the reliance on secondary sources, this represents a notable limitation. Some studies have concluded that apparent corporate intention to act more responsibly is not reflected in the documentary evidence and more activity is suspected than reported (Holcomb et al, 2007; Cowper-Smith and de Grosbois, 2010). While both observations may indeed be correct, the danger is that, in the absence of evidence to the contrary, erroneous conclusions may be drawn. For instance, the partial availability of data may be falsely misconstrued as organizations having something to hide. Unsustainable practices have been omitted altogether from corporate reporting mechanisms and media or carefully 'camouflaged' to conceal them (Moneva et al, 2006). Some systematically 'greenwash' their communications to give the impression of greater commitment in what is otherwise little more than 'veneer environmentalism' (Hawkins and Bohdanowicz, 2012). Nevertheless in the interests of academic balance it is important not to discount the possibility that the opposite may also be true, namely: that there may be more sustainable behaviour being practised in businesses than is currently reported or in the public domain. If this is the case, it raises three connected issues for the discourse on LFAs and sustainable mobilities to which we now turn: the first is what these practices are; second, to understand why these behaviours have not been observed; and third, the extent to which current appraisals of responsibility among LFAs may need to be revisited.

\section{Methods}

A mixed methods strategy was devised to investigate CSR practices among LFAs, comprising two linked phases of data collection between September 2008 and July 2009. First, reported CSR practices were audited as is common practice (Cowper-Smith and de Grosbois, 2010). The nature and level of self-reporting and the type of texts used 
are indicators of organizational approaches to CSR (Mirvis and Googins, 2006; Blowfield and Murray, 2008).

There has been much debate as to what precisely constitutes an LFA within Europe (cf. Dobruszkes 2006; Francis et al 2006; DLR 2011). There is some difficulty in precise ascription because many innovations successfully introduced by airlines like easyJet, Ryanair and Go in the 1990s have been subsequently adopted by full service carriers (Franke 2004), for instance reducing the level of service to enhance (price) competitiveness. Hybrid business models have resulted (Klophaus et al 2012). Some full service airlines have evolved towards the LFA model to varying extents, while other airlines have been launched with intermediate models and positioning (Bjelicic 2007). Some LFAs no longer refer to themselves as such - Flybe uses the term 'regional airline', although the EU still regards it as an LCC (Low Cost Carrier)(2011)- while some LFAs have introduced features (like seat reservations) that used to be the preserve of full service carriers (because of the overheads they entail).

Thus, a layered sampling strategy was employed based on a decision-tree approach. First, all aircraft operators who have permission to fly in the European Union were identified and all airlines without a UK destination were excluded. Second, airlines were selected that described themselves as LFAs or LCCs or who used the language of the low-fares business model in their communications. As a final filter, airlines were deemed to be 'low fares' or 'low cost' if a majority of the standard diagnostic indicators of LFAs applied (i.e. ticket costs, route types and length, network type, fleet type) after a scrutiny of a range of secondary data sources, such as airline reports, the trade press, and trade association documents. A provisional list was prepared and compared to EU listings. It was also circulated to two major LFAs and ELFAA for comment. 
Following this quality assurance process, documentary data were collected for the final sample of 22 airlines (Table 1). It is worth noting that the four largest LFAs in Europe Ryanair (24\%), easyJet (18\%), Air Berlin (11\%) and Flybe (9\%) - account for 62\% of LCC flights in Europe (DLR 2011, p51). During the search of external communications, activities were recorded in such areas as: the environment; charities; ethical codes/reporting; sustainable procurement; and membership of, or connections to, ethical and/or CSR-focused NGOs. Also included, where published, was information about staff (i.e. how the company benefits employees) and communities (i.e. how the company benefits society in a non-profit oriented way). Two types of Content Analysis were conducted. First, macro-level trends were identified based on the type, frequency and size of the documents as proxies for the importance of issues (Hall and Valentin 2005). Second, thematic analysis was undertaken using the analytical framework advanced by Holcomb et al (2007: 466) who broadly categorize CSR practices as they relate to community, environment, marketplace, workforce, and the vision and values of an organization. While this framework does not record the intensity of activity, in a behaviouralist sense it usefully reveals apparent priorities for (or gaps in) action. To establish the validity of the framework for this research, its constructs were examined through, and confirmed by, an intensive programme of observation within one LFA (identity withheld).

In the second phase of data collection, in-depth semi-structured interviews were conducted with senior managers who were the nominated CSR leads for their LFA. In terms of the (organizational) position of the interviewees, the majority reported directly to the board of directors. In some cases, CSR was the principal component in their job descriptions; in others, CSR formed a part of their role or portfolio alongside other duties which commonly included public affairs and public relations. The interviews were designed to reveal more about how CSR was perceived and practiced within the airlines, and they helped to triangulate findings from the Content Analyses. For 
instance, we were able to probe the motives behind some of the more commonlyidentified activities described in the external communications. Conversely, we were also able to question why certain activities which are routinely associated with CSR, were apparently invisible in their texts.

All 22 airlines were invited to participate in the interviews. In total eleven were conducted; they lasted 58 minutes on average; and among this group were representatives of three of the four market leading LFAs mentioned above, as well as a range of the smaller and newer airlines that dominate numerically (DLR 2011). Hence, the sample composition suggests the findings presented below can be generalized widely. The interviews were fully transcribed and the principles of grounded theory were used to drive the analysis (Strauss and Corbin 1990). Four broad themes emerged on which external feedback and verification were garnered. The results presented in Section 4 were initially presented at a meeting of the European Low Fares Airlines Association (ELFAA) in Prague in May 2009. For reasons of ethics and commercial confidentiality in a small community of practice, the interviewees' responses are presented anonymously. For example, we cannot use thumbnail sketches of the respondents and/or the airlines they represented which are routine contextualization in reporting much qualitative research. Even such short descriptive narratives would compromise the anonymity that was a condition of almost every interview. Reported speech has been used extensively below. Idioms, grammatical constructs and particular vocabulary had the potential to reveal interviewees.

[Insert Table 2 near here]

\section{Results}

\subsection{Basic CSR communications}


Four main media were used by LFAs to release responsibility-related information to external audiences (Table 2). At first inspection, six LFAs had not communicated any CSR-related activities through these media. This not to say that $27 \%$ of LFAs did not practice CSR nor act in a socially-responsible manner. Rather, they simply did not record it in these types of texts or it was invisible for some reason. For instance, during the course of the research, Vueling and Clickair merged after which information about the latter's active support for a local environmental charity was removed from its web site (although this activity continued).

Conversely, over two-thirds of LFAs communicated about CSR using one or more of these media. The most frequently-used channel was the web page (used by $11 \mathrm{LFAs}$, $50 \%$ ). This was a manifestation of the lean production principles of the LFA business model and reflected the desire to reduce overheads. Entries in the annual report (10 LFAs, 45\%) were the next most common. Less popular were press releases (8 LFAs, $36 \%$ ) and policy statements related to one or more aspect of CSR (6 LFAs, 27\%). Just four LFAs employed each of the four media, albeit to varying degrees. In addition to easyJet, Flybe and Ryanair (as market leaders), CSR-related policies were produced by four other LFAs (TUIfly, Blue I, transavia and Germanwings). They were owned by the TUI Group, SAS, KLM-Air France, and Lufthansa, and they benefitted from integration within the group reporting apparatus of these major transnational corporations. CSRrelated policy statements varied dramatically in scope and substance. Parent companyproduced texts had clear (i.e. group-related) goals and targets that were reported against in annual reports or dedicated CSR publications. Conversely, although called a 'CSR policy' in the annual report and online, Flybe's text had neither aspirations nor targets, and may be better characterised as a review of the past year's activities. 


\subsection{Stakeholders, communications and content}

This overview provides little detail of the activities or the intended end-users for the texts. CSR-related web communications are deliberately tailored for specific target audiences (Guimarães-Costa and Pina e Cunha 2006). Annual reporting on CSR and CSR-related information was most frequently located in the 'investor relations' section of LFA websites, and the primary audience was primarily those with a (current and future) financial stake in the business -either as shareholders, financiers and/or (corporate) customers. Press releases were found in the parts of the web site primarily intended for the (news) media (as conduits to the general public). Finally, some CSR information which was located elsewhere on the main web site was intended to be accessible to all stakeholders in the 'general public' (including media and investors). However, the information located here was often abridged or focused on different issues than in the annual reports and press releases.

What emerges from this basic analysis of media and audiences is variability both in reporting practices and the nature of content that was delivered. Most LFAs did not communicate to all of the main stakeholder groups and hence the location of the reporting goes some way towards revealing to whom they felt the need to demonstrate responsibility. Seven airlines targeted just one stakeholder audience. Jet2 and bmibaby focused on the news media; Clickair, flyglobespan and MyAir provided information on their general web sites; and SkyEurope and transavia targeted their messages towards investors.

Table 3 reveals the nature of communications to the media in press releases. The principal themes were technological improvements, charity involvements, and community support, including sponsorship of local football teams. Put another way, the 'societal' component of CSR and of the 'triple bottom line' was predominant in numerical terms, with six airlines reporting their charitable involvements and two describing their support for local community initiatives. An important narrative was the contribution 
LFAs could make against a common enemy, illness. Alzheimer's was presented as ‘a devastating condition that robs people of their lives (easyJet 2009: n.p.) while Flybe (2009, np) wanted to combat cancer as 'a disease that touches almost all of us'. Sponsored charities' credentials were set out, along with the LFAs' respective commitments. Charity support was often presented in terms of a quantified amount, although customers were sometimes expected 'to dig deep to support this important cause' (Flybe 2009: online). LFAs assumed the role of facilitator between passengers and charity. Finally, press releases relating to the environment, although less frequent, responded to the need to combat the negative environmental consequences of flying. Variously these announced how recent technological advances (e.g. winglets, newer aircraft, new de-icing fluids) had reduced their impacts. However, the financial implications of their greater pro-environmental actions were not set out.

[Insert Table 4 near here]

The main subjects of the LFAs' web pages were similar (Table 4). Information on attempts to mitigate the environmental impacts of aviation appeared alongside charity involvement. Two airlines (Clickair and TUIfly) hosted information about an environmental charity on their web sites. Both included acknowledgement of the negative externalities of aviation as the underlying reasons for their respective charity support. The length of statements on web sites varied from eight words (Norwegian) to 7,022 words (easyJet). Format, the images included, comprehensiveness and accessibility have been used as surrogates for the importance of CSR for organizations and their priority messages and audience/s (Capriotti and Moreno 2007). Images were largely absent, although some basic data in the form of charts presented the 'CSR case' (such as those on 'Ryanair and the Environment'). easyJet hosted an interactive image detailing the aspects of its environmental commitments, as well as a carbon offsetting 
scheme embedded in the purchasing system. Four other airlines (Blue I, Clickair, Flybe and TUIfly) offered carbon offsetting elsewhere on their web sites.

A further indicator of the significance attached to CSR is the position of issues within the hierarchy of pages on the website as a whole (Coupland 2006): in general, the more mouse-clicks it takes to access information, the less important an issue is deemed to be. No LFA home page hosted any direct CSR-related content (Table 4). Some websites, such as Flybe's, had a link to a CSR-related page in a rollover list; however, in most cases users had to navigate away from a launch page to find CSRrelated information. The most visible (i.e. accessible) CSR-related theme was the environment, with an average of 1.5 clicks to find information. In contrast, charitable information required an average of 2.14 clicks to access information.

\author{
[Insert Table 5 near here] \\ [Insert Table 6 near here]
}

\title{
4.3 CSR in annual reports
}

Ten LFAs included a section on CSR-related issues in annual reporting for 2008 (Table 5). The longest by far, in both words and pages, was SAS Group's section on sustainability (with references to Blue1) which contained 12,454 words over 24 A4 pages. The shortest in words was SkyEurope's 388-word statement. If only LFA-specific reporting is included, the average length of the documents was 1,815 words. As Table 6 indicates, environmental issues dominated. Nine out of the ten reports reviewed LFAs' efforts to reduce their impact on the environment. The other LFA, Norwegian, included a section highlighting its compliance with environmental legislation. Some texts, such as Ryanair's, explicitly presented its environmental efforts as proof that further legislation on the part of national governments (in EU member states) was unnecessary. The annual report statements took a largely techno-centric view of environmental impacts 
and were consistent in tone with the environmental coverage in the press releases and on the web pages.

Workplace issues also appeared in the annual reporting. This was in direct contrast to the web pages where this aspect was conspicuously absent. Employeerelated entries ranged from a basic list of staff conditions and compliance with employment legislation to Lufthansa's concern for the satisfaction of the group's employees in Germanwings. The majority detailed the benefits staff accrued through working for the LFA. These ranged from primary benefits, such as staff flights, to secondary benefits, such as training and advancement opportunities. The emphasis on employees in annual reports also differentiated their content from press releases. Press releases largely overlooked staff conditions, training, benefits and satisfaction which were more potential investor concerns. Instead, press releases presented 'good news' stories that projected LFAs in a positive light at a time when the news media in particular was concentrating on their implications for climate change through rising greenhouse gas emissions (Oxford Economics, 2008; Sustainable Aviation, 2009). Conversely, information on charitable involvements was more comprehensive in the press releases and only heavily abridged versions of the same information was directed towards investors in annual reports.

[Insert Table 7 near here]

\subsection{CSR 'beyond the text'}

As previous studies make clear (Lynes and Andrachuk, 2008; Cowper-Smith and de Grosbois, 2010), such textual sources offer the possibility to form a view about the current state of activity across a sample of airlines, although a lack of comparability limits the value of such conclusions. The same is true here and, as reporting in this manner demonstrates, there is a high degree fragmentation and variability of quality in 
the texts produced by LFAs. This prevents meaningful comparisons; frustrates the drawing of inferences about the nature of activity across the sector; and it clearly points to the limitations in exclusively relying on text-based sources. In fact, the most salient and generalizable conclusion that can be drawn is that the reporting of CSR-related activity by LFAs is relatively poor, and it does not provide the range or depth of information that is likely to satisfy regulators or policy-makers of a commitment to sustainable development.

The interview schedule was, therefore, designed to allow the interviewees maximum opportunity to reveal their knowledge of CSR as it related to their organizations (Table 7). The transcripts were read, discussed and re-read by the research team, to detect bias and false misrepresentations of activity. It quickly became clear that the examples of initiatives, activities or programmes invoked by the interviewees as evidence of responsibility actually existed but, as might be expected, they were presented in a favourable manner. In the initial contact letter, the interviewees had been informed that a text search had been undertaken. Where examples were invoked that were not in the text documents, the interviewees were challenged about their existence. For this reason, we could be certain that they were not fabricated for the purpose of the interviews.

Four major themes emerged from the analysis: interpretations and understandings of CSR; internal practices; the organizational rationale for CSR; and how knowledge related to CSR was circulated and exchanged (i.e. between airlines, across sector, best practice). Overall, the first and third themes were most extensively discussed but the first and second themes revealed the most important insights in the context of this paper and hence deserve discussion here.

\subsubsection{Interpretations and Understandings of CSR}


One of the most striking results associated with the first theme was the variability in how CSR was understood across the sector and, in particular, the absence of an agreed single meta-definition. All interviewees were asked to explain what the term 'corporate social responsibility' meant to them and/or the organization they spoke for (Table 7). While this was a difficult question, no exemplification was offered to encourage spontaneous recall, because the interviewees had been identified as their businesses' leads on CSR. Several respondents were cautious, even somewhat defensive, while others were hesitant, almost seeking reassurance that they had got the 'right' answer. Answers included:

'As any organization, really, you have an ability to influence society around you and to do some good things - also some bad things. But you have the ability to do some good things.'

'I think everyone will say they have a corporate and social responsibility. I think it's how you act it out and what you actually do - that's what makes the difference.'

'In reality, I think there are three axes [sic] of -importance to us in terms of corporate social responsibility: the external - to the outside world, and one inwards, to - to the inside. The number one is the environment. Number two is the people.'

Several interviewees attempted to interpret CSR by invoking examples of activity which they perceived connected with, or tangibly demonstrated, their LFA's commitment to a more responsible approach. Typically these included: staff training; employee recruitment and retention; community projects; and charity involvement. Other interviewees understood CSR in terms of the airline's and the sector's contribution to the wider goals of sustainable development. Most responses employed standard ideas about job creation, enhancing outbound accessibility, and the opening of new markets to 
inbound traffic and investment, all of which were very reminiscent of the trade association's position (ELFAA, 2004). In some cases, these latter responses also included specific mention of work with charities, community issues and sponsorship of groups, associations and clubs.

Nobody was able to rehearse a polished, standard (i.e. 'textbook') answer perhaps resulting either from their prior professional development (i.e. picked up in a masters or MBA) or from an existing relationship with a trade association or CSR accreditation scheme. On one level this was understandable because there is no universal agreement about, or single definition of, the concept (Dahlsrud, 2008; Okoye 2009). As one respondent put it:

'....that's a hard question to answer because I think it means different things to me than it does to [the airline sector as a whole] since I come from a different, more corporate background.... it's mainly been about philanthropy: add-ons to business that are CSR-related have most been philanthropy.'

On another level these responses raised suspicions about the LFAs' commitment to more responsible business administration. Put another way, if organizational leads were unable to convey the multi-dimensional nature of the concept, was responsibility which should be a major, cross-cutting operational approach (Porter and Kramer 2006)only really a superficial concern?

From our work embedded in an LFA observing its practices, we were able to calibrate its lead's answer against what we knew (independently) to be happening. The answer was brief and did not faithfully represent the scope of activity in other divisions of the business. Clearly, this points to a potential limitation where (elite) interviews exclusively are relied upon as data sources. Subjectivity, bias or 'spin' were anticipated as problems; in fact, incomplete knowledge was a more significant shortcoming. All the transcripts were compared with the content analysis and their respective texts. Only in a minority of cases was there close overlap between sources in terms of examples. The 
latter was the case for smaller airlines and because the CSR lead also had the portfolio for public affairs and public relations (i.e. they produced the texts). For the majority of the LFAs, however, there were differences, some notable in scope. Some examples invoked by the interviewees were not recorded in their texts. Conversely, documentary analysis revealed a variety of initiatives or schemes which the managers did not always recall. There were two common reasons for this disjuncture: first, that very few LFAs had conducted a systemic audit of CSR-related activity; and second, that not all examples of activity appeared in the texts because they were selectively composed for particular audiences.

Finally on this theme, two over-arching sets of ideas were mentioned by almost every interviewee to be connected to CSR to one degree or another: the environment alongside charity and philanthropy. Emblematic of this was one respondent for whom, 'CSR is a bit of philanthropy, a bit of community, a bit of the way in which you earn your money. We did report on our CSR ....but it was really just two pages of philanthropy.'

Viewed in context, this was reasonably predictable. Although contemporary research has stressed that CSR is more than corporate philanthropy (Porter and Kramer, 2002; Sasse and Trahan, 2007), at a practical level this is a highly visible means by which a business can relatively easily and tangibly demonstrate its commitment to all its stakeholders, internal and external. As noted above, charity was -and remains- an easily understood concept for the news media and general public. Environment was (and still is) a major public relations topic for LFAs. Not surprisingly then, all the interviewees took the opportunity to present (i.e. 'spin') their approach to managing and mitigating impacts as responsible. For instance:

'On the environment, we feel that we are not exempt, even though we are a young airline and we have a nice, a fairly new fleet. We don't feel that we're exempt 
entirely from what we provide - or what we contribute - to....the environment.'

Other considerations predicted by the literature were absent. For example, transnational corporations face the challenge of implementing CSR in their home market as well in overseas markets which sometimes have different (regulatory and cultural) expectations of responsibility (Blowfield and Murray 2008). A distinctive feature of LFAs is the number of communities they serve and hence to whom they should be (socially) responsible. In almost all of the interviews, the examples of community- and charitable-activity were from the states and regions in which LFA headquarters were located. This was explicitly couched in terms of the relative ease to administer CSRrelated activities at home, but it was clear that most of the interviewees had simply not thought about spatial differences in expectation or delivery of the type discussed by Coles et al (2011).

\subsubsection{Internal CSR practices}

The second theme covered knowledge of how and why the LFAs attempted to embed a more responsible approach into their internal practices. Most managers conceded that their general support for CSR had not been translated more extensively into systematic behaviours and/or structured formal actions in whole business approaches. Various reasons were advanced for this and the lack of CSR policies, strategies and reports produced by LFAs. Some explained it as linked to the relative youthfulness of the sector and the lack of 'institutional memory':

'We're a young company .... we as a management team, we're just beginning to feel now that we have the time now and the resources to deal with issues that would fall under corporate social responsibility.'

Others argued that the global economic downturn had forced LFAs to concentrate on 
their core operations and competencies. Put starkly, one respondent noted that an LFA: '.... should be profitable, because if you don't make a profit, you don't survive and there's not much you can do as an ex-airline. That is the start.'

Others were concerned at the level, availability and deployment of human resources for strategic CSR. Perhaps not surprisingly, given the importance of cost-cutting and lean production in LFA business models, there was some suspicion of the additional overheads that a more extensive approach may generate, and whether requests for additional resource would be justifiable or agreed by executive boards:

'....being as leanly staffed as we are, obviously, we don't have the sort of comfort of being able to produce this sort of reports [sic].'

'We couldn't afford it. We are thinking about creating a dedicated section on the website, but it — again, it would be very basic, probably using the language from the annual report and simply making it more easily available.... We want to make it more accessible to people but again, it's the limitations of a low cost organisation.'

Of course, in theory a more responsible approach should incur no additional costs because responsibility should be embedded in, or a part of, everything an organization does (Porter and Kramer, 2006; Blowfield and Murray, 2008). Some interviewees noted that activity was already being conducted in areas which are routinely identified with CSR like purchasing, employee relations, and community engagement. However, such initiatives were not currently or explicitly badged as 'CSR' and, as one interviewee reflected,

'We do it but we don't realize it. I do think we - through our everyday business practices - we support communities, train our staff, are environmentally responsible. [But] I don't think we're in a position where we could write an annual CSR report.' 
Thus, for some businesses at least one principal challenge appears to be to co-ordinate more extensive and efficient information-gathering and dissemination of current activity across the business. There was no doubt among the interviewees that a plethora of data was already being produced for other (regulatory) reasons which could (additionally, without extra cost) capture, monitor and evaluate CSR activity. As one respondent observed, the lack of CSR reporting was a major missed opportunity:

'The honest truth is, where is the benchmarking? Who knows? This is an industry where you can measure lots of things. I've never worked in an industry where everything is so measurable.'

In several LFAs responsibility for CSR was shared across departments or divisions. A nominated lead (i.e. the interviewee) typically fulfilled a co-ordinating role; however, beyond their promotion of responsibility as an organizational ethos or principal, actual delivery was typically tasked to other senior managers, for instance in human resources, marketing, logistics and supply chain management. The interviews revealed a dilemma. Embedding a more responsible approach across a business was recognized as a gradual, progressive and long-term process, as it is in the literature (Mirvis and Googins 2006). However, it was noted that these other 'delegated' senior managers had to prioritize other short-term imperatives in a lean organization in a competitive environment. Strategizing for CSR was often relegated behind other business concerns.

\section{Discussion and conclusion}

This paper explored CSR practices among low fares airlines flying to and from the UK as portrayed textually in external communications and revealed in a series of interviews. There has been considerable discourse about the role of LFAs in sustainable mobility and sustainable tourism circles, but this research suggests that existing positions in this 
debate may need revisiting. To date, these have been heavily informed by secondary data sources and observations from outside the firm. This paper demonstrates that CSR texts produced by LFAs are highly fragmented, lacking in detail, and often selective in their coverage based on their intended audiences. They are not straightforward to synthesize nor, if used exclusively, do they represent a reliable basis for judging the extent to which LFAs - either individually or as a sector- have responded in practice to the principles of sustainable development. Moreover, as the interviews and their juxtaposition with the textual sources indicate, the full or exact extent to which LFAs act responsibly is extremely difficult to assess precisely in the absence of a common understanding of the term, more complete data collection, and greater consistency among LFAs in their reporting.

This lack of an effective evidence base, as well as the epistemological and methodological challenges in compiling one, have policy and conceptual implications which cannot be separated, nor ignored. The debate between LFAs and their critics regarding sustainable mobilities hinges on the credibility of LFAs as part of a highly deregulated sector to act responsibly, and so allay the need for governmental intervention. To make the case that they act responsibly, more detailed and comprehensive data are required. This research suggests there is some way to go before sector-wide reporting of CSR-related activities is more routine, systematic, and comparable in nature, timing and content. Even then, editorial practices will still limit listings. In terms of public affairs, the problem is that a partial evidence base of the type uncovered by this research hardly substantiates the LFA position or inspires trust among regulators. As Cowper-Smith and de Grosbois (2010 p72) observe with respect to 'flag carriers', there is often a notable difference between an apparent commitment to the major goals of CSR and the limited data presented to substantiate their claims. This research concurs with their view. However, an important qualification is also necessary; this is not to say that such activity is not happening 'beyond the text', as it 
were, because only secondary data sources have been used so far in extant research to inform this discussion. We should not discount the possibility that there are instances of 'covert sustainability', but we should not speculate what this may be. Further empirical research is essential therefore.

The interviews conducted here hint very strongly at activity 'behind the scenes' which would usefully contribute to a fuller discussion of LFAs in the context of sustainable mobilities, but to which there is not yet full access. Care has to be taken with the language here. 'Covert' is meant in the sense of latent, that is, not in view. Dictionary definitions suggest other synonyms such as 'hidden' or 'obscured' although to use them here may (erroneously) imply a certain type of agency and/or a particular set of motives that would not entirely be justified. For instance, they may insinuate that LFAs were trying to conceal or camouflage (Moneva et al 2006) unsustainable behaviours in a manner akin to 'veneer environmentalism' or 'greenwashing' (Hawkins and Bohdanowicz 2012). Alternatively, such words may suggest that there was a desire to keep their activity hidden, not for negative reasons but because the CSR managers were fearful of a 'Catch 22 ' in the form of a negative hearing in the 'court of public opinion' (Kolk and Pinske, 2006; Morsing et al, 2008) Both have somewhat conspiratorial connotations but the reasons here were more banal. Consensus from the interviews was that LFAs simply did not have, nor had allocated, adequate resources for fuller auditing of their CSR activities, although data sources existed within the businesses that could have assisted this task.

A continuum of reporting styles is not proposed, for instance from camouflaging through covert sustainability to greenwashing and veneer environmentalism: nor is a typology of reporting being suggested based on two axes of level of concealment and strength of adherence to the principles of sustainable development. Both would be empirically problematic to corroborate. Rather, the data presented here point toward the limitations of the overt behaviourialist nature of the current discourse on LFAs and 
research more widely on CSR in the tourism sector. There are clear echoes back to Lukes' seminal critique (1974) of power discourse in the social sciences; in order to develop a more complete view of LFAs and sustainable mobilities there is a need to consider what is obvious, clear and visible while not being too literal and thereby excluding what may be obscure, or invisible, at first inspection. A more literal view, that relies solely on the observable, is likely to offer a limited, possibly misleading, understanding of the phenomenon (in Lukes' case, power - here, the level of CSR activity).

Extant discourse on LFAs and sustainable mobilities has almost exclusively reported what is directly observable by commentators outside the firm; for understandable reasons it routinely overlooks the somewhat counter-intuitive position of considering what may be (currently) unobservable. The problem is that external perspectives relying solely on documentary analysis will, almost always, only present partial insights into activities, both within and outside LFAs in terms of CSR. A more appropriate empirical solution would to be to employ a wider range of sources in mixed methods research strategies to overcome potential shortcomings with individual methods and techniques. Interviews offer a major possibility beyond texts; however, interviews cannot be relied upon either singularly or because the knowledge of key informants of the practices within their businesses is far too incomplete. Moreover, risks associated with bias have to be properly mitigated. A combination of archival work, observation and interviewing with researchers embedded within firms and across their internal divisions, is necessary if the limitations of text-based conclusions are to be overcome and future policy and practice are to be properly evidence-based.

[Acknowledgements - to be inserted on acceptance - see separate file]

\section{References}


Amaeshi, K.M. and Crane, A. (2006) Stakeholder engagement: a mechanism for sustainable aviation. Corporate Social Responsibility and Environmental Management, 13, 245-260.

Barr, S.W., Shaw, G. and Coles, T.E. (2011) Sustainable lifestyles: sites, practices and policy. Environment and Planning A 43, 3011-3029.

Bohdanowicz, P. and Zientara, P. (2008) Corporate social responsibility in hospitality: issues and implications. A case study of Scandic. Scandinavian Journal of Hospitality and Tourism, 8, 271-293.

Bohdanowicz, P. and Zientara, P. (2009) Hotel companies' contribution to improving the quality of life of local communities and the well-being of their employees. Tourism and Hospitality Research, 9, 147-158.

Bohdanowicz, P.,Zientara, P. and Novotna, E. (2011). International hotel chains and environmental protection: an analysis of Hilton's we care! programme (Europe, 2006-2008). Journal of Sustainable Tourism, 19(7), 797-816

Bjelicic, B. (2007) The business model of low cost airlines — past, present, future. In Groß, S. and Schröder, A. (eds) Handbook of Low Cost Airlines: Strategies, Business Processes and Market Environment. Berlin: Erich Schmidt Verlag.

Blowfield, M. and Murray, A. (2008) Corporate Responsibility. A Critical Introduction. Oxford: Oxford University Press.

Capriotti, P. and Moreno, A. (2007) Corporate citizenship and public relations: the importance and interactivity of social responsibility issues on corporate web sites. Public Relations Review, 33, 84-91.

Coles, T.E., Fenclova, E. and Dinan, C. (2011) Responsibilities, recession and the tourism sector: perspectives on CSR among low-fares airlines during the economic downturn in the UK. Current Issues in Tourism, 14: 519-536.

Commission of the European Communities. (2006) Implementing the Partnership for Growth and Jobs: Making Europe a Pole of Excellence on Corporate Social 
Responsibility. Online document. Available from: http://eur-

lex.europa.eu/LexUriServ.do?uri=COM:2006:0136:FIN:EN:PDF (Last accessed: 25 November 2008).

Coupland, C. (2006) Corporate social and environmental responsibility in web-based reports: Currency in the banking sector?. Critical Perspectives on Accounting, 17, $865-881$.

Cowper-Smith, A. and de Grosbois, D. (2010) The adoption of corporate social responsibility practices in the airline industry. Journal of Sustainable Tourism, $19,59-77$.

de Grosbois, D. (2012) Corporate social responsibility reporting by the global hotel industry: commitment, initiatives and performance. International Journal of Hospitality Management, 31, 896-905.

Dahlsrud, A. (2008) How corporate social responsibility is defined: an analysis of 37 definitions. Corporate Social Responsibility and Environmental Management, 15, 113.

Department for Transport (DfT) (2003) The Future of Air Transport. London: HMSO. Deutsches Zentrum für Luft- und Raumfahrt e.V. (DLR) (2011) Annual Analysis of the European Air Transport Market - Annual Report 2009. Braunschweig: German Aerospace Centre.

Dobruszkes, F. (2006) An analysis of European low-cost airlines and their networks. Journal of Transport Geography, 14, 249-264.

Dodds, R. and Joppe, M. (2005) CSR in the Tourism Industry? The Status of and Potential for Certification, Codes of Conduct and Guidelines. Washington, DC: CSR Practice, Foreign Investment Advisory Service, Investment Climate Department.

Duval, D.T. (2008) Aeropolitics, global aviation networks and the regulation of international visitor flows. in Coles, T.E. and Hall, C.M. (eds.) International 
Business and Tourism. Global Issues, Contemporary Interactions (pp.91-105).

Abingdon: Routledge.

easyJet. (2008) Annual Report and Accounts 2008. Online document. Available from: http://2008annualreport.easyjet.com/?id=23538 [Last accessed: 01 April 2008].

Environmental Change Institute (ECI). (2005) Predict and Decide: Aviation, Climate Change and UK Policy. Oxford: ECI and University of Oxford.

European Low Fares Airline Association (ELFAA). (2004) Liberalisation of European Air Transport: the Benefits of Low Fares Airlines to Consumers, Airports, Regions and the Environment. Online document. Available from: http://www.elfaa.com/ documents/ ELFAABenefitsofLFAs2004.pdf [Last accessed: 14 July 2009].

Flybe. (2008) Annual Report and Accounts 2007/08. Online document. Available from: http://www.flybe.com/pdf/Annual_Report_Complete_(Lo-Res_Final).pdf [Last accessed: 01 April 2009].

Francis, G., Humphreys, I., Ison, S. and Aicken, M. (2006) Where next for low cost airlines? A spatial and temporal comparative study. Journal of Transport Geography, 14, 83-94.

Franke, M. (2004) Competition between network carriers and low-cost carriersretreat battle or breakthrough to a new level of efficiency?. Journal of Air Transport Management, 10, 15-21.

Gibbons, J. (2008) Climate to pay price for low-cost flying. The Irish Times, 07 July 2008. Online document. Available from: www.irishtimes.com/newspaperopinion/2008/0710/1215537698972.html [Last accessed: 14 July 2009].

Gössling, S. and Peeters, P. (2007) "It does not harm the environment!" An analysis of industry discourses on tourism, air travel and the environment. Journal of Sustainable Tourism, 15, 402-417. 
Graham, B. and Shaw, J. (2008) Low-cost airlines in Europe: reconciling liberalization and sustainability. Geoforum, 39, 1439-1451.

Groß, S. and Schröder, A. (2007) Basic Business Model of European Low Cost Airlines An Analysis of Typical Characteristics. in Groß, S. and Schröder, A. (eds) Handbook of Low Cost Airlines: Strategies, Business Processes and Market Environment, Berlin: Erich Schmidt Verlag.

Guimarães-Costa, N. and Pina e Cunha, P. (2008) The Atrium effect of website openness on the communication of corporate social responsibility. Corporate Social Responsibility and Environmental Management, 15, 43-51.

Hall, C.M. and Valentin, A. (2005) Content analysis. in: Ritchie, B.W., Burns, P.M. and Palmer, C.A. Tourism Research Methods: Integrating Theory with Practice (pp191209). Wallingford: CAB International.

Hawkins, R. and Bohdanowicz, P. (2012) Responsible Hospitality. Theory and Practice. Oxford: Goodfellow Publishers.

Holcomb, J. L., Upchurch, R. S. and Okumus, F. (2007) Corporate Social Responsibility: What Are Top Hotel Companies Reporting?. International Journal of Contemporary Hospitality Management, 19, 461-475.

International Air Transport Association (IATA) (2012a). Use aviation to drive economic growth and jobs - UK aviation policy is a great opportunity. Online document, dated 25/04/2012. Available from: http://www.iata.org/pressroom/pr/pages/2012-04-25-01.aspx [Last accessed: 01 October 2012].

International Air Transport Association (IATA) (2012b). Climate Change. Online document. Available from: https://www.iata.org/whatwedo/environment/pages/climate change.aspx [Last accessed: 01 October 2012]. 
Kolk, A. and Pinkse, J. (2006) Stakeholder mismanagement and corporate social responsibility crises. European Management Journal, 24, 59-72.

Klophaus, R., Conrady, R. and Fichert, F. (2012) Low cost carriers going hybrid: evidence from Europe. Journal of Air Transport Management, 23, 54-58

Lukes, S. (1974, 2005) Power: A Radical View. London: Macmillan(reissued)

Lynes, J.K. and Andrachuk, M. (2008) Motivations for corporate social and environmental responsibility: a case study of Scandinavian airlines. Journal of International Management, 14, 377-390.

Miller, G. (2001) Corporate responsibility in the UK tourism industry. Tourism Management, 22, 589-598.

Mann, D. (2004) Calls to control low-cost flights. BBC News, 24 April 2004. Online document. Available from: http://news.bbc.co.uk/1/hi/sci/tech/ 3625931.stm [Last accessed: 14 July 2009].

Mirvis, P. and Googins, B. (2006) Stages of corporate citizenship. California Management Review, 48, 104-126.

Moneva, J. M., Archel, P., and Correa, C. (2006) GRI and the camouflaging of corporate unsustainability. Accounting Forum, 30, 121-137.

Morsing, M., Schultz, M. and Nielsen, K.U. (2008) The 'Catch 22' of communicating CSR: findings from a Danish study. Journal of Marketing Communications, 14, 97-111.

Okoye, A. (2009) Theorising corporate social responsibility as an essentially contested concept: is a definition necessary?. Journal of Business Ethics, 89, 613-27.

Omega. (2009) OMEGA Community Noise Study: Indices to enhance understanding \& management of community responses to aircraft noise exposure. Online document. Available from: http://www.omega.mmu.ac.uk/Events /OMEGA\%20Noise\%20Report\%20Final\%2026-2-09\%20RD\%20270209.pdf [Last accessed: 04 February 2010].

Oxford Economics. (2009) Aviation: the real World Wide Web. Online document. 
Available from: http://www.oef.com/OE_FA_IntSects.asp [Last accessed: 24 July 2009].

Plume, K. (2008) CSR - Einführendes zu einem Trend. in Gate eV (eds) Corporate Social Responsibility im Tourismus (pp.20-25). Berlin: GATE - Netzwerk, Tourismus, Kultur eV.

Phillips, E.D. (2006) Corporate social responsibility in aviation. Journal of Air Transportation, 11, 65-87.

Porter, M. E., and Kramer, M. R. (2006) Strategy \& society: the link between competitive advantage and corporate social responsibility. Harvard Business Review, December, 1-14.

Porter, M.E. and Kramer, M.R. (2002) The competitive advantage of corporate philanthropy. Harvard Business Review, December, 5-16.

Rey, B., Myro, R. and Galera, A. (2011) Effect of low-cost airlines on tourism in Spain: a dynamic panel data model. Journal of Air Transport Management, 22, 163-67

Sasse, C.M. and Trahan, R.T. (2007) Rethinking the new corporate philanthropy. Business Horizons, 50, 29-38.

Sheldon, P. and Park, S-Y. (2011) An exploratory study of corporate social responsibility in the US travel industry. Journal of Travel Research, 50, 392-407.

Sinclair, A. (2007) Soaring future for cheap flights?. BBC News, 11 June 2007. Online document. Available from: http://news.bbc.co.uk/1/hi/england/ 6740145.stm [Last accessed: 24 July 2009].

Strauss, A. L. and Corbin, J. (1990) Basics of Qualitative Research: Grounded Theory Procedures and Techniques, London: SAGE.

Treasury, Her Majestys and Revenue \& Customs. (2008) Aviation Duty: a Consultation. London: HM Treasury.

World Business Council on Sustainable Development (1999) Corporate Social Responsibility: Meeting Changing Expectations. Online document. Available 
from:

http://www.wbcsd.org/pages/edocument/edocumentdetails.aspx?id=82\&nose archcontextkey=true [Last accessed: 01/10/2012].

York Aviation. (2007) Social Benefits of Low Fares Airlines in Europe. Online document. Available from: http://www.elfaa.com/documents/Social Benefits of LFAs in Europe_(York)_211107.pdf [Last accessed: 14 July 2009]. 
Table 1: Low-fares airlines included in the sample

\begin{tabular}{|c|c|c|c|}
\hline Airline & Fleet Size & Head-quarters & Ownership \\
\hline $\begin{array}{l}\text { Air Baltic } \\
\text { Corporation }\end{array}$ & 31 & Latvia & $\begin{array}{l}\text { Latvian State }(52.6 \%) \text { and } \\
\text { Baltijas aviācijas sistēmas SIA } \\
(47.2 \%)\end{array}$ \\
\hline Air Berlin & 131 & Germany & Publically listed \\
\hline Air Southwest & 5 & UK & $\begin{array}{l}\text { Subsidiary of Sutton Harbour } \\
\text { Group }\end{array}$ \\
\hline $\begin{array}{l}\text { Aurigny Air } \\
\text { Services }\end{array}$ & 11 & UK & State of Guernsey \\
\hline Blue1 & 13 & Finland & SAS Group (100\%) \\
\hline Bmibaby & 20 & UK & $\begin{array}{l}\text { Subsidiary of British Midland } \\
\text { Airways }\end{array}$ \\
\hline easyJet* & 165 & UK & Publically listed \\
\hline Flybe* & 77 & UK & $\begin{array}{l}\text { Rosedale Aviation Holdings Ltd } \\
(69 \%) \text {, British Airways (15\%), } \\
\text { staff }(16 \%)\end{array}$ \\
\hline flyglobespan & 14 & UK & Globespan Group \\
\hline Germanwings & 27 & Germany & Deutsche Lufthansa AG \\
\hline Jet2.com* & 30 & UK & Subsidiary of Dart Group plc \\
\hline MyAir.com*† & 8 & Italy & Flyholding, S.p.A. \\
\hline NIKI & 12 & Austria & $\begin{array}{l}\text { Private investors, Air Berlin } \\
(24 \%)\end{array}$ \\
\hline $\begin{array}{l}\text { Norwegian Air } \\
\text { Shuttle* }\end{array}$ & 40 & Norway & Publically listed \\
\hline Ryanair* & 190 & Ireland & Publically listed \\
\hline SkyEurope* & 15 & Slovakia & Publically listed \\
\hline transavia.com* & 34 & Netherlands & Subsidiary of KLM \\
\hline TUIfly & 44 & Germany & Subsidiary of TUI AG \\
\hline Vueling $\neq$ & \multirow[t]{2}{*}{35} & \multirow[t]{2}{*}{ Spain } & \multirow{2}{*}{$\begin{array}{l}\text { Merged in } 2009, \text { part owned by } \\
\text { Iberia ( } 45 \%)\end{array}$} \\
\hline Clickair* ${ }^{*}$ & & & \\
\hline Wind Jet & 12 & Italy & Finaria Group \\
\hline Wizz Air* & 26 & Hungary & Private investors \\
\hline
\end{tabular}

Sources: authors 
Table 2: CSR in LFA Communications in 2009 (Source: authors)

\begin{tabular}{|c|c|c|c|c|}
\hline Airline & $\begin{array}{c}\text { CSR-related } \\
\text { webpages }\end{array}$ & $\begin{array}{l}\text { CSR-related press } \\
\text { release/s }\end{array}$ & CSR in annual report & CSR-related policy \\
\hline Air Baltic Corporation & no & no & $\mathrm{N} / \mathrm{A}$ & no \\
\hline Air Berlin & no & yes & $2006,2007,2008$ & no \\
\hline Air Southwest & yes & yes & $\mathrm{N} / \mathrm{A}$ & no \\
\hline Aurigny Air Services & no & no & $\mathrm{N} / \mathrm{A}$ & no \\
\hline Blue1 & yes & yes (last issued 2007) & Included in SAS's Annual Report 2004-2008 & $\begin{array}{c}\text { Environmental policy, SAS's sustainable } \\
\text { development strategy }\end{array}$ \\
\hline bmibaby & no & yes & $\mathrm{N} / \mathrm{A}$ & no \\
\hline Clickair & yes & no & $\mathrm{N} / \mathrm{A}$ & no \\
\hline easyJet & yes & yes & $2006,2007,2008$ & $\begin{array}{l}\text { Environmental policy, charity policy, } \\
\text { ethical code }\end{array}$ \\
\hline Flybe & yes & yes & 2008 & CSR policy \\
\hline flyglobespan & yes & no & $\mathrm{N} / \mathrm{A}$ & no \\
\hline Germanwings & yes & no & $\begin{array}{c}\text { In Lufthansa's Sustainability Balance Report 2006- } \\
\text { 2009, also in Annual Report 2002- } 2008\end{array}$ & $\begin{array}{l}\text { CSR issues in Lufthansa's corporate } \\
\text { policy, corporate environmental policy }\end{array}$ \\
\hline Jet2.com & no & yes & No & no \\
\hline MyAir.com & yes & no & $\mathrm{N} / \mathrm{A}$ & no \\
\hline NIKI & no & no & $\mathrm{N} / \mathrm{A}$ & no \\
\hline Norwegian Air Shuttle & yes & no & 2007,2008 & no \\
\hline Ryanair & yes & yes & $2003-2008$ & Ethical code \\
\hline SkyEurope & no & no & 2007,2008 & Ethical code \\
\hline transavia.com & no & no & $2007 / 2008,2008 / 2009$ & CR policy \\
\hline TUIfly & yes & no & $\begin{array}{c}\text { In TUI Group's Annual Report 2005-2008 and the } \\
\text { bi-annual Sustainability Reporting 2006/2007 }\end{array}$ & TUI Group's environmental policy \\
\hline Vueling & no & no & $\mathrm{N} / \mathrm{A}$ & no \\
\hline Wind Jet & no & no & $\mathrm{N} / \mathrm{A}$ & no \\
\hline
\end{tabular}


Table 3: CSR themes in 2008/09 Press Releases

\begin{tabular}{|l|c|c|c|}
\hline Airline & Environment & Charity & Other \\
\hline Air Berlin & $\begin{array}{c}\text { Technological } \\
\text { improvements }\end{array}$ & $\begin{array}{c}4 \text { sponsored } \\
\text { chairites }\end{array}$ & \\
\hline Air Southwest & & & Community support \\
\hline Bmibaby & $\begin{array}{c}\text { Fundraising for BBC } \\
\text { Children in Need } \\
\text { appeal }\end{array}$ & \\
\hline easyJet & improvements & $\begin{array}{c}\text { Sponsorship of } \\
\text { Cancer Research UK }\end{array}$ & $\begin{array}{c}\text { Football } \\
\text { sponsorship } \\
\text { Staff Training } \\
\text { Community support }\end{array}$ \\
\hline Flybe & $\begin{array}{c}\text { Technological } \\
\text { improvements }\end{array}$ & $\begin{array}{c}\text { Fundraising for } \\
\text { Cancer Research UK } \\
\text { sponsorship }\end{array}$ \\
\hline Jet2.com & & Community support \\
\hline Ryanair & & & \\
\hline
\end{tabular}

(Source: authors, based on published press releases 01/10/08-01/07/09, full bibliographical details available in: REF removed for anonymity) 
Table 4: CSR information on selected LFA web sites

\begin{tabular}{|c|c|c|c|c|}
\hline Airline & Environment & Charity & \multicolumn{2}{|c|}{ Other } \\
\hline & Click through & Click through & Subject & Click through \\
\hline Air Southwest & 1 & - & - & - \\
\hline Blue1 & 2 & - & $\begin{array}{c}\text { Corporate } \\
\text { responsibility } \\
\text { [social, } \\
\text { environmental, } \\
\text { economic] }\end{array}$ & 2 \\
\hline Clickair & \multicolumn{2}{|c|}{ [environmental charity] $\mathbf{2}$} & - & - \\
\hline \multirow[b]{2}{*}{ easyJet } & \multirow[b]{2}{*}{1} & \multirow[b]{2}{*}{2} & Sustainability & 2 \\
\hline & & & $\begin{array}{l}\text { CSR [redirects } \\
\text { to online } 2008 \\
\text { annual report] }\end{array}$ & 3 \\
\hline Flybe & 1 & 2 & - & - \\
\hline flyglobespan & 1 & 2 & - & - \\
\hline Germanwings & - & - & $\begin{array}{c}\text { Football } \\
\text { sponsorship }\end{array}$ & 3 \\
\hline MyAir.com & - & 3 & - & - \\
\hline $\begin{array}{l}\text { Norwegian Air } \\
\text { Shuttle }\end{array}$ & - & - & $\begin{array}{c}\text { Corporate } \\
\text { responsibility } \\
\text { [charity] }\end{array}$ & 2 \\
\hline Ryanair & 2 & - & - & - \\
\hline TUIfly & [environme & al charity] 2 & - & - \\
\hline
\end{tabular}

Source: authors 
Table 5: CSR in 2008 Annual Reports: Basic Content Analysis

\begin{tabular}{|c|c|c|c|}
\hline Airline & $\begin{array}{c}\text { In parent } \\
\text { company's report? }\end{array}$ & $\begin{array}{c}\text { Number of A4 } \\
\text { pages }\end{array}$ & $\begin{array}{c}\text { Number of } \\
\text { words }\end{array}$ \\
\hline Air Berlin & no & 6 & 2,163 \\
\hline Blue1 & SAS & 24 & 12,454 \\
\hline easyJet & no & 8 & 7,022 \\
\hline Flybe & no & 3 & 1,044 \\
\hline Germanwings & Lufthansa & 3 & 2,153 \\
\hline Norwegian Air Shuttle & no & 1 & 624 \\
\hline Ryanair & no & 2 & 852 \\
\hline SkyEurope & no & 2 & 388 \\
\hline transavia.com & no & 1 & 610 \\
\hline TUIfly & TUI Group & 8 & 2,946 \\
\hline
\end{tabular}

Source: authors 
Table 6: Breakdown of CSR in LFAs' annual reports in 2008

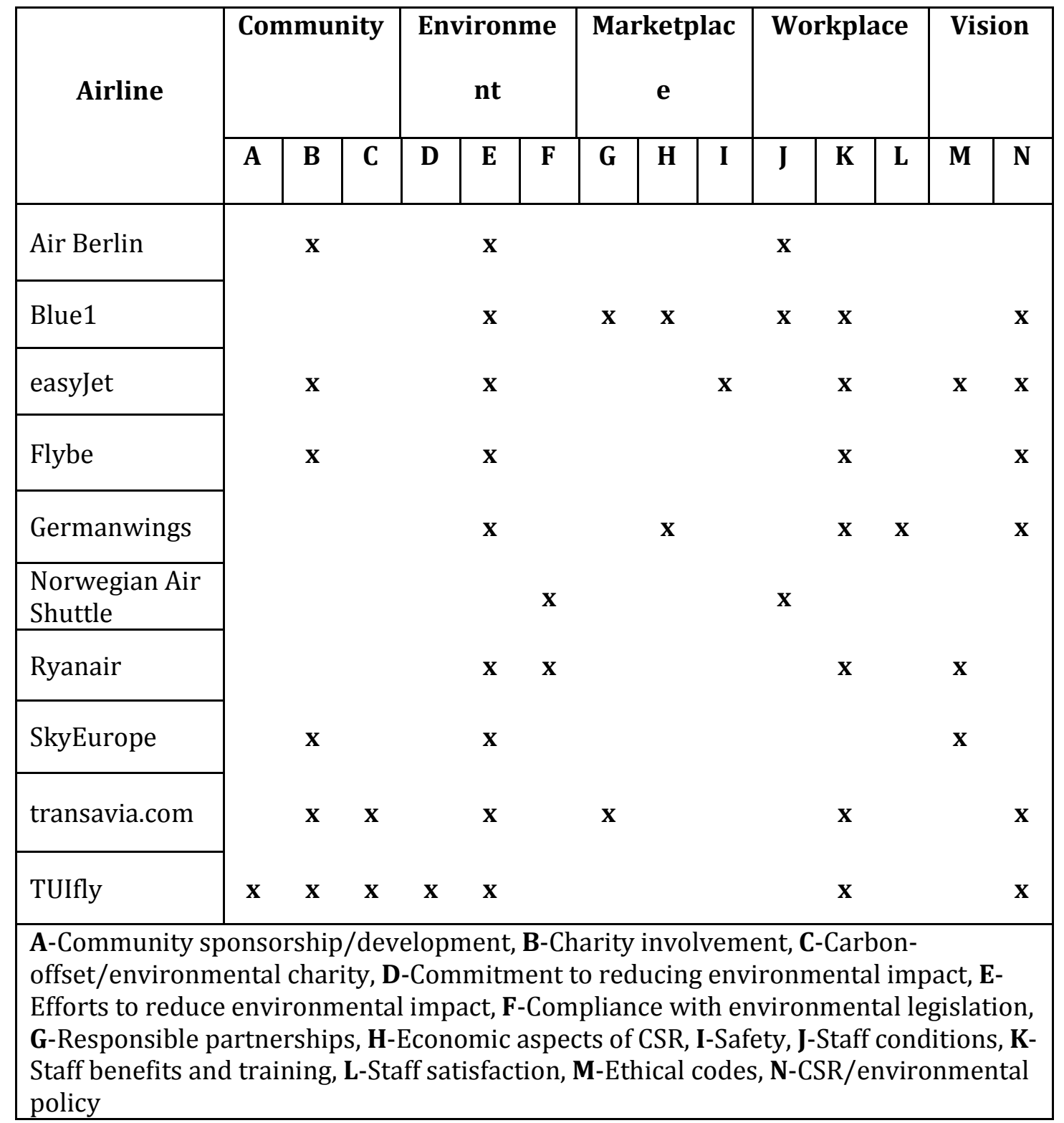

Source: data authors; matrix categories based on Holcomb et al (2007) 
Table 7. Key 'departure points' for the semi-structured interviews

- What does 'corporate social responsibility' mean to you / your organisation?

- What are the costs and benefits to airlines acting in a socially responsible manner?

- Which other airline CSR strategy/ies are good / best practice in your view?

- What components should be included in an ideal aviation CSR strategy?

- How do you practice corporate social responsibility?

- What are the costs / benefits of acting in a responsible manner for your business?

- Do you have a formal corporate social responsibility statement?

- What are main issues / challenges in compiling / managing / running your strategy?

- How have other stakeholders been involved in developing your CSR work?

Source: authors 